
не фикция: основные события Международной ярмарки non/fictio@№ 18

Реферат. Подводятся итоги Международной ярмарки интеллектуальной литературы non/fictio№ 18 , проходившей 30 ноября -4 декабря 2016 г. в Центральном доме художника в Москве. В рамках ярмарки традиционно проводятся творческие и профессиональные встречи, конференции, презентации и мастер-классы. Рассказывается об основных профессиональных событиях ярмарки, значимых для книжной и библиотечной общественности. Презентуется проект единого отраслевого календаря, призванный координировать поток мероприятий книжной отрасли и формировать единое культурно-литературное пространство. Особое внимание уделяется презентации библиофильского издания М.В. Сеславинского «Русские книжные редкости XX века: 333 избранные книги».

Ключевые слова: книгоиздание, книгораспространение, non/fiction, пропаганда чтения, защита интеллектуальной собственности, единый календарь мероприятий.

Для цитирования: Cтарых М.Д. Интеллектуальная литература - не фикция: основные события Международной ярмарки non/fictio№ 18 // Библиотековедение. 2016. Т. 65, № 6. С. 645-648.

$\mathrm{T}$ радиционным книжным предновогодним праздником стало открытие Международной ярмарки интеллектуальной литературы non/fictio№ 18. В событии были задействованы около 300 участников из 20 стран, 400 мероприятий, разделенных на девять дискуссионных зон, прошли в режиме «нон-стоп». Ярмарка заняла всю площадь Центрального дома художника на Крымском валу, обеспечив посетителей максимально возможным пространством книжного маркета. Для удобства навигации покупателей был создан специальный топ-лист изданий, в который была включена 171 книга; 79 книг попали в детский список лучших изданий. Работу выставки контролировал экспертный совет, в который вошли известные специалисты книжной отрасли, следящие за качеством представленной продукции и координацией проводимых мероприятий.

Раздел "Антикварная книга» стал преемником книжной антикварной ярмарки, отдельная площадь была отведена гастрономической книге и пространству «Vinyl Club», являющемуся местом

\author{
Мария Дмитриевна \\ Старых, \\ Российская государственная библиотека, \\ отдел периодических изданий, \\ редактор \\ Воздвиженка ул., д. $3 / 5$, \\ Москва, 119019, Россия \\ E-mail: StarykhMD@rsl.ru
}

распространения мультимедийных продуктов. Специальная программа иллюстраторов «Комикс как часть книжной культуры» собрала желающих на ряд творческих и профессиональных встреч.

В 2016 г. впервые за всю историю Международной ярмарки интеллектуальной литературы ее почетным гостем стала Великобритания. Британский совет - организация, развивающая сотрудничество в области образования и культуры между Великобританией и другими странами, в том числе Россией, - подготовил обширную программу мероприятий с участием знаковых бри- 


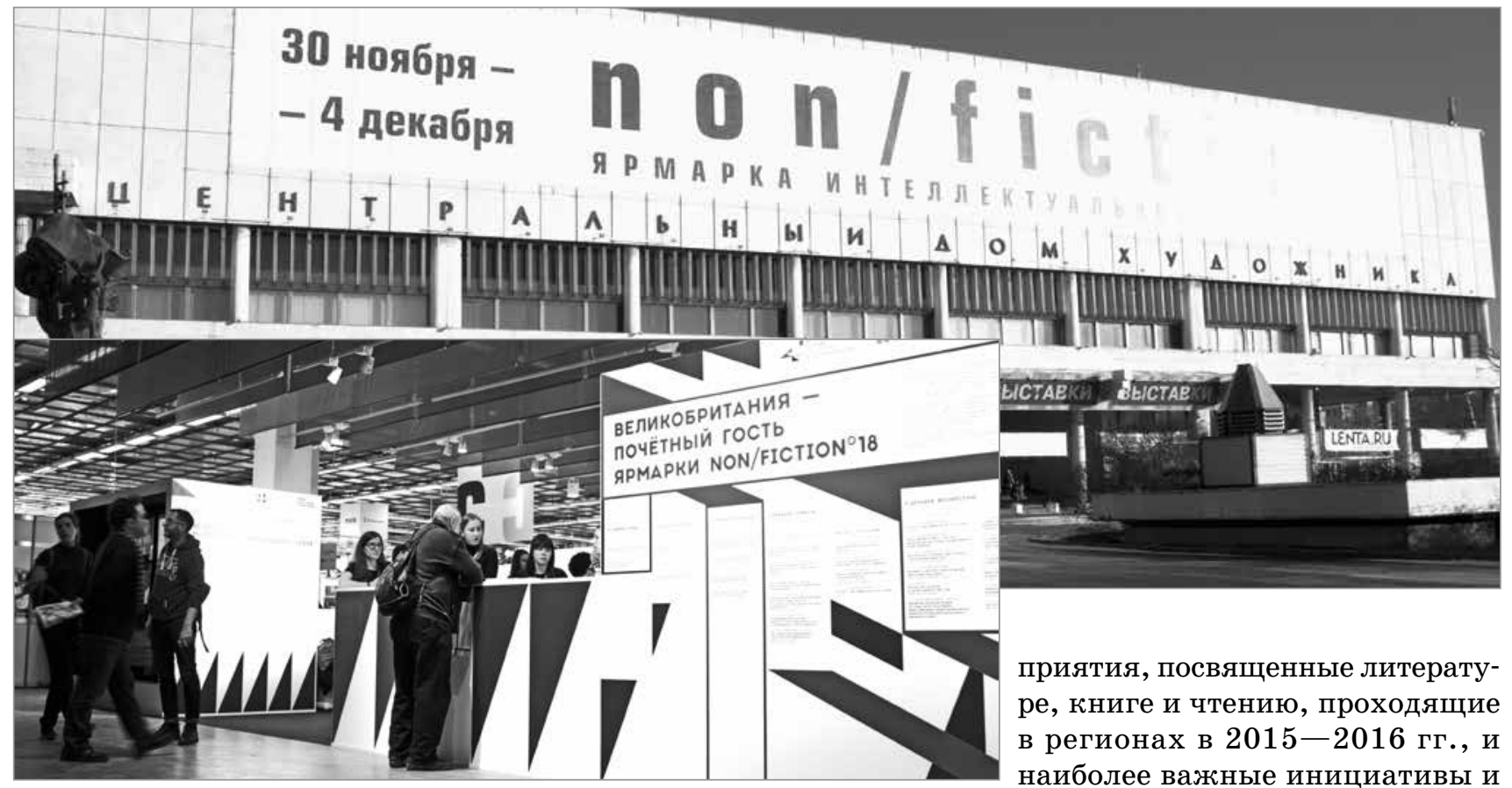

танских писателей, а также кино- и театральных сценаристов, иллюстраторов, историков. В non/ fictio№ 18 приняла участие и большая делегация издателей, приехавшая для установления профессиональных контактов с российскими коллегами. Директор Британского совета в России М. Бёрд, предваряя открытие ярмарки, отметил: «Любовь к литературе - это то, что объединяет русских и британцев, и сегодня особенно важно говорить об общечеловеческих ценностях. Программа, представленная нами на ярмарке - яркая мозаика британских голосов. Хочется представить писателей, не столь известных в России, но горячо любимых нашими соотечественниками» .

Специальный представитель Президента РФ по международному культурному сотрудничеству M.Е. Швыдкой рассказал журналистам о том, что «следующий год станет Годом науки и образования между нашими странами».

В 2016 г. администрацией ярмарки учреждена премия non/fiction, направленная на пропаганду качественной литературы и независимых интеллектуальных издательств, которая будет представлять книгу как часть индустрии. Через год профессионалы определят победителей в номинациях: «Книжная торговля», «Библиотечное дело», «Медиа» и «За заслуги» .

В рамках ярмарки состоялось награждение участников Всероссийского конкурса «Самый читающий регион» среди субъектов федерации на звание «Литературный флагман России», призванного популяризировать чтение и развивать книжные проекты. В 2016 г. в конкурсе приняли участие 84 из 85 регионов Российской Федерации. Члены жюри во главе с президентом Российского книжного союза С.В. Степашиным оценивали конкурсные заявки, включающие значимые меро- достижения органов власти и учреждений культуры в развитии инфраструктуры книги и чтения и поддержании литературных традиций регионов.

Флагманом 2016 г. была признана Воронежская область, которая славится своим богатейшим литературным и культурным наследием. Дипломантами конкурса стали также Астраханская область, Красноярский край, Республика Татарстан, Санкт-Петербург, Свердловская область.

Важным профессиональным событием ярмарки стала конференция «Единый отраслевой календарь как способ интеграции и взаимодействия участников книжной индустрии». Представители российской книжной области (издатели, книготорговые организации, библиотеки) проводят множество важных и общественно значимых мероприятий, посвященных книге и чтению. Однако детальный анализ масштабных отраслевых проектов «Культурная карта России. Литература. Чтение» и Всероссийского конкурса «Самый читающий регион» показал, что большинство этих мероприятий носит разрозненный и не скоординированный характер. Целью конференции стало рассмотрение и анализ лучших практик продвижения книги и чтения и обсуждение методики разработки единого отраслевого календаря книжных дат, мероприятий и событий - проекта, впервые представленного на 29-й Московской международной книжной выставке-ярмарке [1]. Главный редактор журнала «Книжная индустрия» С.Ю. Зорина призвала коллег к участию в формировании единого культурно-литературного пространства, насыщенного важными и интересными отраслевыми событиями, дополненными не только текстовыми описаниями, но также фото- и видеоматериалами. Начальник отдела книжных выставок и пропа- 
ганды чтения Роспечати А.Н. Воропаев, являющийся идеологом проекта [2], отметил важность планирования мероприятий на два года вперед для оптимального взаимодействия профессионалов отрасли и удобства читателей. Руководитель Генеральной дирекции международных книжных выставок и ярмарок С.В. Кайкин уточнил, что не все мероприятия нужно разводить по датам - некоторые, напротив, следует объединить для максимального привлечения внимания СМИ. В работе конференции приняли участие представители большинства отраслевых ассоциаций, в том числе Ассоциация книгораспространителей независимых государств (руководитель сети книжных магазинов «Московский Дом Книги», президент АСКР Н.И. Михайлова), Ассоциация книгоиздателей России (генеральный директор издательства «Белый город», президент АСКИ К.В. Чеченев), Гильдия книжников (президент торгового дома «БИБЛИО-ГЛОБУС», президент Гильдии книжников Б.С. Есенькин). К.В. Чеченев выразил сожаление в связи с тем, что многие ассоциации не принимают участия в формировании единого календаря, а значит, его работа будет менее эффективна, и выразил надежду на консолидацию усилий.

Координатор рабочей группы Российской библиотечной ассоциации (РБА) «Библиотеки и социальные медиа» Е.А. Шибаева в выступлении, посвященном вопросам интеграции с существующими отраслевыми календарями и проектами, рассказала об аналогичных проектах (сводный план библиотечных мероприятий, новостной канал на сайте РБА, АИС «Единое информационное пространство в сфере культуры» (ЕИПСК) и др.). Интегративные возможности таких систем, как АИС ЕИПСК [3], позволяют эффективно использовать значительный накопленный массив информации и данных, полученных системой от библиотечного сообщества, не только в работе библиотек и в социальных сетях, но и обеспечить их поступление в СМИ на федеральном и на региональном уровнях. При разработке отраслевого календаря мероприятий книжной индустрии имеет смысл учесть возможность технологии заимствования событий системами, сократив трудозатраты непосредственных исполнителей проектов, которые вынуждены многократно переписывать одни и те же данные, подстраивая их под требования различных систем.

Заместитель генерального директора издательской группы «ЭКСМО-АСТ» М.Б. Лозовский обратил внимание на необходимость продвижения проекта за рубежом, так как Европа активно заинтересована в популяризации чтения, и такой календарь может успешно интегрироваться в международное профессиональное сообщество. Кроме того, важно дополнить график основными законодательными инициативами в области книжного дела и интеллектуальной собственно- сти с целью информирования профессионалов о новейших изменениях.

Главный редактор журнала «Читаем вместе. Навигатор в мире книг» Ю.Б. Гнездилова напомнила о том, что нельзя забывать конечного потребителя - читателя, а для этого следует создать максимально понятный интерфейс портала и провести кампанию популяризации проекта.

Члены рабочей группы обратились к библиотечному сообществу с просьбой принять активное участие в создании единого отраслевого календаря и поделиться опытом работы по ведению автоматизированных систем для выработки оптимальной методики взаимодействия с членами профессионального содружества и читателями.

Заметным мероприятием ярмарки стала презентация книги руководителя Федерального агентства по печати и массовым коммуникациям и известного столичного библиофила М.В. Сеславинского «Русские книжные редкости XX века: 333 избранные книги» [4]. Издание продолжает традицию составления каталогов книжных редкостей, заложенную еще в конце XIX в. отечественными собирателями - Г.Н. Геннади, И.М. Остроглазовым, Н.И. Березиным и др. Впервые представлена обширная, богато иллюстрированная подборка библиофильских дезидерат минувшего столетия, среди них - первые книги известных поэтов и писателей, редкие книги русского авангарда, малотиражные библиофильские издания, наиболее значительные и редкие детские книги, уничтоженные издания и др. Значительная часть описаний снабжена примерами продаж на западных и российских аукционах, а также краткими авторскими комментариями. Книга адресована широкому кругу читателей, библиофилам, а также профессионалам в области истории, литературы и книжного дела.

Неизменная и важнейшая составляющая ярмарки - обширная детская программа на площадке «Территория познания». По сложившейся традиции последних лет, на non/fictio№ 18 был выделен отдельный этаж для представителей детского книгоиздания.

Тема детской программы «Читай, рассказывай, спорь» ставит целью включить детей и родителей в разговор о важности чтения, обсуждения книг, о формировании собственного отношения к прочитанному. В фокусе внимания - книги, которые провоцируют споры и обсуждения, помогают определять жизненную позицию и вырабатывать собственное мнение. На «Территории познания» прошли встречи с лучшими российскими и зарубежными авторами и книжными иллюстраторами, различные творческие мастерские, мастер-классы, игры-квесты, выставки иллюстраций и др. Отдельный акцент был сделан на мероприятиях для родителей и специалистов по детскому чтению, дабы помочь взрослому работать с детской книгой, создавая вокруг нее интересное и 
живое пространство, научить активно обсуждать с ребенком происходящее в книге и т. д.

Не всем известно, что название Международной ярмарки интеллектуальной литературы изначально означало вовсе не «нехудожественную литературу», как теперь думают многие ее посетители. Один из организаторов и идейных вдохновителей ярмарки, критик А.Ф. Гаврилов, предложил игру слов: интеллектуальная литература в нашей стране - «не фикция». Тезис и в этот раз подтвердили более 35 тыс. человек, пришедших зарядиться позитивной атмосрерой книжного знания, повысить профессиональный уровень и поучаствовать в масштабном литературном празднике.

\section{Cписок источников}

1. Cmapыx М.Д. Неделя профессионального вдохновения: итоги 29-й Московской международной книжной выставки-ярмарки // Библиотековедение. 2016. T 65, № 5. С. 550-555.

2. Bоропаев A.H. «В график!»: о создании сводного календаря мероприятий книжной отрасли // Книжная индустрия. 2016. № 7 (139). С. 66-67.

3. Жерновой Ф.Е. Единое информационное пространство в сфере культуры // Медиатека и Мир. 2015. № 3. С. $9-12$.

4. М.С.[Сеславинский М.В.] Русские книжные редкости XX века: 333 избранные книги / Рос. гос. б-ка. Москва : Пашков дом, 2016. 381 с.

Фото М.Д.Старых

\title{
Intellectual Literature - is not a Fiction: the Major Events of the International Book Fair Non/Fictio№ 18
}

Maria D. Starykh, The Russian State Library, 3/5 Vozdvizhenka Str., Moscow, 119019, Russia E-mail: StarykhMD@rsl.ru

\begin{abstract}
There are summarized the results of the International Book Fair of Intellectual Literature Non/ Fictio№ 18, held on 30 November - 4 December, 2016 in the Central House of Artists in Moscow. In the framework of the Book Fair there are traditionally held creative and professional meetings, conferences, presentations and workshops. The major professional events of the fair, significant for book and library community, are described. The project on the unified sectoral calendar, designed to coordinate the flow of events of the book industry and form the unified cultural and literary space, is presented. Special attention is paid to the presentation of the bibliophilic edition of M.V. Seslavinsky "Russian Book Rarities of the 20th century: 333 Selected Books".
\end{abstract}

Key words: Book Publishing, Book Distribution, Non/Fiction, Promotion of Reading, Intellectual Property Protection, Unified Calendar of Events.

Citation: Starykh M.D. Intellectual Literature - is not a Fiction: the Major Events of the International Book Fair Non/Fictio№ 18, Bibliotekovedenie [Library and Information Science], 2016, vol. 65, no. 6, pp. $645-648$.

\section{References}

1. Starykh M.D. Nedelya professional'nogo vdokhnoveniya: itogi 29-i Moskovskoi mezhdunarodnoi knizhnoi vystavki-yarmarki [The Week of Professional Inspiration: the Results of the 29th Moscow International Book Fair], Bibliotekovedenie [Library and Information Science], 2016, vol. 65, no. 5, pp. 550-555.

2. Voropaev A.N. "V grafik!": o sozdanii svodnogo kalendarya meropriyatii knizhnoi otrasli ["Into the Schedule!": the Creation of the Master Calendar of the
Book Industry Events], Knizhnaya industriya [Book Industry], 2016, no. 7 (139), pp. 66-67.

3. Zhernovoi F.E. Edinoe informatsionnoe prostranstvo v sfere kul'tury [Unified Information Space in the Sphere of Culture], Mediateka i Mir [Mediatheque and the World], 2015, no. 3, pp. 9-12.

4. M. S. (Seslavinsky M.V.) Russkie knizhnye redkosti XX veka: 333 izbrannye knigi [Russian Book Rarities of the 20th Century: 333 Selected Books]. Moscow, Pashkov Dom Publ., 2016, 381 p. 